\title{
Association of vascular endothelial growth factor protein expression according to muscle fiber types with diet and exercise intervention in diet-induced obese rats
}

\author{
홍창배 · 천우광 · 김기진
}

계명대학교

\begin{abstract}
Hong, Chang-Bae., Cheon, Woo-Kwang., Kim, Ki-Jin. Association of vascular endothelial growth factor protein expression according to muscle fiber types with diet and exercise intervention in diet-induced obese rats. Exercise Science, 22(1): 85-94. 2013. This study measured vascular endothelial growth factor (VEGF) protein expression of different skeletal muscle fiber types after a 6-week intervention of energy restriction and exercise in diet-induced obese rats. The changes in protein expression were analyzed across the different 6-weeks intervention programs of diet, exercise, and diet plus exercise. After intake of high fat diet for 6-weeks, obesity-induced groups showed a significantly higher body weight as compared to control group. The diet plus exercise (B) group showed a significantly lower visceral fat volume after 6-weeks, and obese group showed a higher visceral fat volume than the other groups. Diet alone group, and diet plus exercise (B) group showed a significantly higher VEGF protein expression in red gastrocnemius muscle after 6-weeks of treatment as compared to the pre-level of control group. The diet alone group, exercise group, and diet plus exercise (B) groups showed a significantly higher VEGF protein expression in white gastrocnemius muscle after 6-weeks of treatment as compared to the pre-level of obese group, but these groups showed no significant differences as compared to the pre-level of control group. The exercise group showed a significantly higher VEGF protein expression in soleus muscle after 6-weeks of treatment as compared to the pre-level of the control group, and the exercise group and diet group showed a significantly higher VEGF protein expression in soleus muscle after 6-weeks of treatment as compared to the post-level of the control group. In conclusion, VEGF protein expression of type IIb fibers in gastrocnemius white muscle showed a significant activation after exercise.
\end{abstract}

Key words : Vascular endothelial growth factor (VEGF), Obesity, Diet, Exercise

\section{초 록}

홍창배, 천우광, 김기진. 비만 흰쥐의 6주간 식이와 운동 처치후 골격근 유형별 VEGF 단백질 발현의 변화. 운동과학, 제 22 권 제1호, 85-94, 2013. 본 연구는 고지방 식이를 이용하여 비만을 유도한 비만 휜쥐를 대상으로 6주간의 식이제한, 운동요법, 식이제한과 운동요법을 병행하여 비만처치를 적용하여 골격근 섬유의 특성에 따른 VEGF 단백질의 발현 양상을 비교한 결과 다음과 같은 결론을 얻었다. 체중의 변화를 살펴본 결과 6 주간의 고지방 식이는 일반식이를 섭취한 통제그룹에 비해 체중을 증가시키는데 유효한 방법이며, 체중 감소를 위한 처치 프로그램으로는 운동그룹, 식이제한과 운동병행 $\mathrm{B}$ 그룹에서 체중 감 소가 나타났다. 내장지방량을 측정한 결과 식이제한과 운동병행 $\mathrm{B}$ 그룹이 유의하게 낮은 결과를 나타냈으며, 비만그룹이 모 든 그룹에 비해 내장지방량이 상대적으로 높은 결과를 나타냈다. 일회성 운동전 비복근 적근의 VEGF 단백질 발현은 식이제 한그룹, 식이제한과 운동병행 B그룹이 통제그룹에 비해 높았다. 일회성 운동전 비복근 백근의 VEGF 단백질 발현은 운동그 룹, 식이제한과 운동병행 $\mathrm{A}, \mathrm{B}$ 그룹이 비만그룹보다 높은 VEGF 단백질 수준을 나타냈다. 일회성 운동전 가자미근의 VEGF 단 백질 발현은 운동그룹이 비만처치전 통제그룹에 비해서 높은 VEGF 단백질 수준을 나타냈다. 또한 식이제한그룹과 운동그룹 이 비만처치후 통제그룹에 비해서 높은 VEGF 단백질 수준을 나타냈다. 이상의 결과를 요약하면 골격근에서의 VEGF 단백질 발현은 type IIb 섬유의 특성을 가지고 있는 비복근 백근에서 운동에 따른 유의한 증가가 관찰되었다.

주요어 : 혈관내피성장인자(VEGF), 비만, 다이어트, 운동 


\section{I . Introduction}

It has been reported that the expression of vascular endothelial growth factor (VEGF) plays a key role in changing capillary vessels through exercise training (Gavin \& Wagner, 2001 ; Olfer et al., 2001 ; Gustafsson et al., 2001).

From the point of view that the density and number of capillary vessels are closely related to the activation of the oxidizing energy system, VEGF protein level can be changed at the point of being obese and also in the process of obesity treatment, where the capability of oxidation of skeletal muscle is low. In the case of obese people, who undergo intense, occasional-endurance exercise for four weeks, an increase in the density of capillary vessels in muscular fibers with type I and type II fibers has been noted. However, no differences in the level of VEGF and basic fibroblast growth factor (bFGF) in endothelial cell and skeletal muscle have been observed (Jensen et al., 2004). The influence of exercise (one of the artificial methods to induce hypoxia) on the VEGF protein level of muscle in 12 week-old male rats was apparent with higher VEGF protein and capillary density in skeletal muscles in the exercise groups than control group (Gu et al., 2006 ; Tang et al., 2004). Based on an increase in VEGF protein expression through exercise, along with Fms-like tyrosine kinase 1 receptor (Flt-1) and VEGF-specific receptor, participating in angiogenesis, exercise would be considered as a key index to observe angiogenesis (Birot et al., 2003).

The degree of VEGF expression varies depending on the fiber type composition of skeletal muscle or contraction characteristics, consequently, higher levels of VEGF mRNA expression in the gastrocnemius has been observed due to exercise and electrical stimulation, and expression was higher in type I than type II fiber (Brutsaert et al., 2002).

The result of electrical stimulation on the tibialis anterior and the extensor digitorum longus in rat, the expression of the VEGF gene is increased according to transformation from type II fiber to type I fiber. In addition, VEGF expression may vary depending on the number and density of capillary vessels and oxidization capability. Therefore, VEGF expression provides the possibility of playing an important role in growing capillary vessels and muscular fiber transformation (Annex et al., 1998).
Studies on the effects of obesity and VEGF expression have been conducted according to the position of VEGF protein formation and physiologic responses. However, previous research on body weight changes after obesity treatment and VEGF expression in skeletal muscles are not sufficient.

Therefore, this study aimed to access changes in VEGF protein expression within muscle fiber types both, pre and post-obesity treatments of diet alone, exercise alone, and both diet and exercise carried out in obese-induced rats fed a high-fat diet.

\section{Method}

\section{Subject}

In this study, two-weeks-old Sprague-Dawley male rats were randomly divided into the following six groups : control group, obesity group, diet group, exercise group, diet and exercise combined(A) group, and diet and exercise combined(B) group. Each group consisted of 8 rats at the beginning; however, a few rats were sacrificed during sampling or experiments. The number of rats in each group is listed below 〈Table 1〉. Rats were given two weeks to adapt to the new environment and six weeks for development of diet-induced obesity, so the rats were 11-weeks old before obesity treatment, and 17-weeks old after treatment.

Table 1. Formation of subjects

\begin{tabular}{ccc}
\hline Group & $\begin{array}{c}\text { Pre- } \\
\text { treatment }\end{array}$ & $\begin{array}{c}\text { Post- } \\
\text { treatment }\end{array}$ \\
\hline Control $(\mathrm{n}=16)$ & 8 & 8 \\
Obesity $(\mathrm{n}=10)$ & 8 & 2 \\
Diet $(\mathrm{n}=6)$ & 6 \\
Exercise $(\mathrm{n}=6)$ & 6 \\
Diet and Exercise Combined A $(\mathrm{n}=4)$ & 4 \\
Diet and Exercise Combined B $(\mathrm{n}=5)$ & 5 \\
\hline
\end{tabular}

\section{Method}

\section{1) Feeding experiment}

The rats were housed two per cage. The temperature of the 
breeding room was $22-24{ }^{\circ} \mathrm{C}$ with a relative humidity of $50 \%$, and brightness controlled per 12 hours. Rats in the obesity group were fed with specialized feeds (high fat $50 \%$ ) for six weeks to induce obesity. Control group rats were fed with regular chow (Samyangsa, Korea) and were provided an exact amount of feedstuff using a microbalance. The obesity group was fed freely and was not provided with any kind of obesity treatment. Obesity treatment groups were divided into four types : diet alone, exercise alone, diet and exercise combined(A), and diet and exercise combined(B). The amount of diet fed and the body weight of rats were recordedon a weekly basis.

\section{2) Diet-induced obesity program for 6-weeks}

Diet-induced obesity was conducted for 6-weeks for each group. To induce obesity, two-week old rats were freely fed with more than $30 \%$ fat content feeds and more than $20 \mathrm{~g}$ of feeds. For two weeks before the initiation of diet-induced obesity program, rats were subjected to treadmill running at $15-16 \mathrm{~m} / \mathrm{min}$ on a $6-8 \%$ gradient for 20 minutes, and 5 times per week in order to be adaptable to exercise regimen during obesity treatment. The control group was fed with chow containing $65.4 \%$ carbohydrate, $11.5 \%$ fat, $22.1 \%$ protein, and $1.0 \%$ others. Other groups except for the control groups were fed with feeds containing $47.5 \%$ carbohydrate, $31.8 \%$ fat, 19.2 $\%$ protein and $1.3 \%$ others (experimental diet).

3) Obesity treatment program with experimental diet for 6 weeks

- Diet Group : fed only $10 \mathrm{~g}$ per day without exercise

- Exercise Group : fed more than $20 \mathrm{~g}$ per day without control, and aerobic exercise by treadmill running at $20 \sim 25 \mathrm{~m} / \mathrm{min}$, at 6-8 \% grade for 60 minutes, 6 times per week.

- Diet \& exercise combined(A) (Combined A) : fed only 13 $\mathrm{g}$ per day, and aerobic exercise by running treadmill at 20-25 $\mathrm{m} / \mathrm{min}$, on a 6-8 \% gradient for 45 minutes, 3 times per week.

- Diet \& exercise combined(B) (Combined B) : fed only 10 $\mathrm{g}$ per day, and aerobic exercise by running treadmill at
20-25 $\mathrm{m} / \mathrm{min}$, on a 6-8 \% gradient for 60 minutes, 3 times per week.

\section{4) Tissue extraction}

When the rats were 11-weeks old, before the initiation of obesity treatment program, 8 rats were sacrificed from the control group and obesity group. When rats were 17-weeks old, after the 6-week obesity treatment program, the control group, obesity group and all the obesity treatment groups were sacrificed. After the rats were anesthetized by placing them into a case containing ether-dipped cotton, the rats were taken out and their limbs were fixed on a dissecting plate. Fat around the testicles was extracted to measure visceral fat. To reduce position error of extraction, only one inspector extracted the fat from the same spot in all the rats. Both the hind legs were extracted for muscle samples to analyze VEGF protein in gastrocnemius and soleus muscles. In case of the gastrocnemius, which has distinct traits between white muscle and red muscle, each white and red muscle was extracted separately. Two parts of gastrocnemius and soleus were separately extracted and then frozen in liquid nitrogen. They were stored at $-80{ }^{\circ} \mathrm{C}$ until analysis.

\section{Analysis method}

\section{1) Measurement of body weight and fat tissue}

The body weights of rats were measured once per week from the period of adaptation and obesity inducement to obesity treatment. To measure visceral fat weight, the entire fat around the testicles was completely extracted and weight was recorded up to two decimal places by microbalance.

2) VEGF protein extraction in skeletal muscle and western blotting analysis

To extract protein from tissue, a solution containing $150 \mathrm{mM}$ $\mathrm{NaCl}, 5 \mathrm{mM}$ EDTA, 50 mM Tri-HCl(pH 8.0), 1 \%-NP 40, 1 mM aprotinin, $0.1 \mathrm{mM}$ leupeptin, and $1 \mathrm{mM}$ pepstatin was added into tissue and the tube was placed in ice. After tissue homogenization (PRO-200 homogenizer, PRO Scientific, USA), the sample was centrifuged (micro centrifuge VS-15000CF, 
Vision Scientific Co. Ltd) at $14,000 \mathrm{rpm}$ for 20 minutes at $4{ }^{\circ} \mathrm{C}$ and then the supernatant was used for protein analysis. The supernatant was weighed at exact amount by using a protein assay kit (Bio-Rad Protein assay, Bio-Rad Laboratories, USA), and weighed protein was kept at $-70{ }^{\circ} \mathrm{C}$ for western blotting analysis.

\section{(1) SDS-PAGE}

The $10 \%$ separating gel $(30 \%$ acrylamide : bisacrylami de, 1.5M tris pH8.8, $10 \%$ SDS, TEMED, $10 \%$ ammo nium persulfate) and $5 \%$ stacking gel $(30 \%$ acrylami de : bisacryiamide, $1 \mathrm{M}$ tris $\mathrm{pH}$ 6.8, $10 \%$ SDS TEMED, and $10 \%$ Ammonium persulfate) were used for SDS-PAGE. After mixing the centrifuged supernatant (at 14,000 rpm for 20min) with SDS loading buffer (60 mM tris pH 6.8, $25 \%$ glycerol, $2 \%$ SDS, 14.4 mM 2-mercaptoethanol, and $0.1 \%$ Bromophenol blue), the sample was boiled at $100{ }^{\circ} \mathrm{C}$ for 10 minutes to denature protein. After cooling down, the denatured protein was centrifuged again at 13,000 rpm for 10 minutes at $4{ }^{\circ} \mathrm{C}$. Each sample along with a standard marker (SDS-PAGE Molecular Weight Standards, BioRad, USA) was divided into equal portions with a protein content of $20 \mu \mathrm{g}$ and placed on the stacking gel well-prepared by Mini-Protein II dual-slab apparatus (Bio-Rad, USA). The samples were electrophoresed at 80 volts for 2 hours until the tracking dye reached the bottom of the gel.

\section{(2) Western blot analysis}

The electrophoresed gel, PVDF membrane (Millipore) soaked in transfer buffer (190 mM glycine, $50 \mathrm{mM}$ Tris-base, $0.05 \%$ SDS, and $20 \%$ methanol), Whatman $3 \mathrm{M}$ paper, PVDF membrane (Millipore, USA), and Whatman 3M paper were folded in order, and equipped with Trans-blot SD semi-dry transfer system (Bio Rad, USA), and then they were transferred at 6 volts for 90 minutes. After membrane deposition, membrane and $7 \%$ skimmed milk solution (in TBST : $10 \mathrm{mM}$ Tris-base pH 8.0, $150 \mathrm{mM} \mathrm{Nacl}$, and 0.05\% Tween-20) were placed in a plastic container located above the rocker platform in $4{ }^{\circ} \mathrm{C}$ freezer, and then blocked by over-night incubation. The next morning, skimmed milk solution was discarded, and membrane was washed three times with TBST for 10 minutes/wash. The membrane was incubated with polyclonal anti-VEGF antibody (sc-152, Santacruz, CA) at a dilution $1: 500$ with TBST $(10 \mathrm{ml})$ for $90 \mathrm{~min}$ for antibody response. Subsequently, the membrane was washed three times with TBST solution for $10 \mathrm{~min} /$ wash. Later on, the membrane was incubated with secondary antibody (goat anti-rabbit IgG conjugated secondary antibody) for one hour at a dilution of 1:600 solution using ECF western blotting kit (Amersham Biosciences, Japan). The membrane was then washed three times with TBST solution for $15 \mathrm{~min} /$ wash. Next, the membrane was incubated with the tertiary antibody, AP (anti-rabbit Ig fluorescein-linked whole Ab, Amersham Biosciences, Japan) at a dilution $1: 2,500$ for one hour, and then washed three times with TBST solution for $15 \mathrm{~min} /$ wash. The membrane was fully covered with ECF substrate using pipette, and then wrapped completely by vinyl wrap. Immediately, the membrane was scanned using molecular imager FX Systems (Bio-Rad, USA), and the images were saved. The relative strength of each band from the image was calculated with equal amount using Quantity One program (Bio-Rad, USA).

\section{Statistics}

The mean and standard deviation of measured data were calculated by SPSS 11.0. To verify the difference in VEGF expression in skeletal muscle according to treatment method of each group, one-way ANOVA was used. After obesity treatment, two-way ANOVA was used to verify the differences between each group and times based on the method of treatment. The significance level was $p<.05$. If the result of analysis showed statistical significance, post-hoc test was implemented by Tukey method.

\section{Results}

\section{Changes in body weight}

The changes in body weight of each group are shown in $\langle$ Table 2$\rangle$.

Based on one-way ANOVA of body weight between pre- and 
Table 2. Changes in body weight in each group according to time of measurement

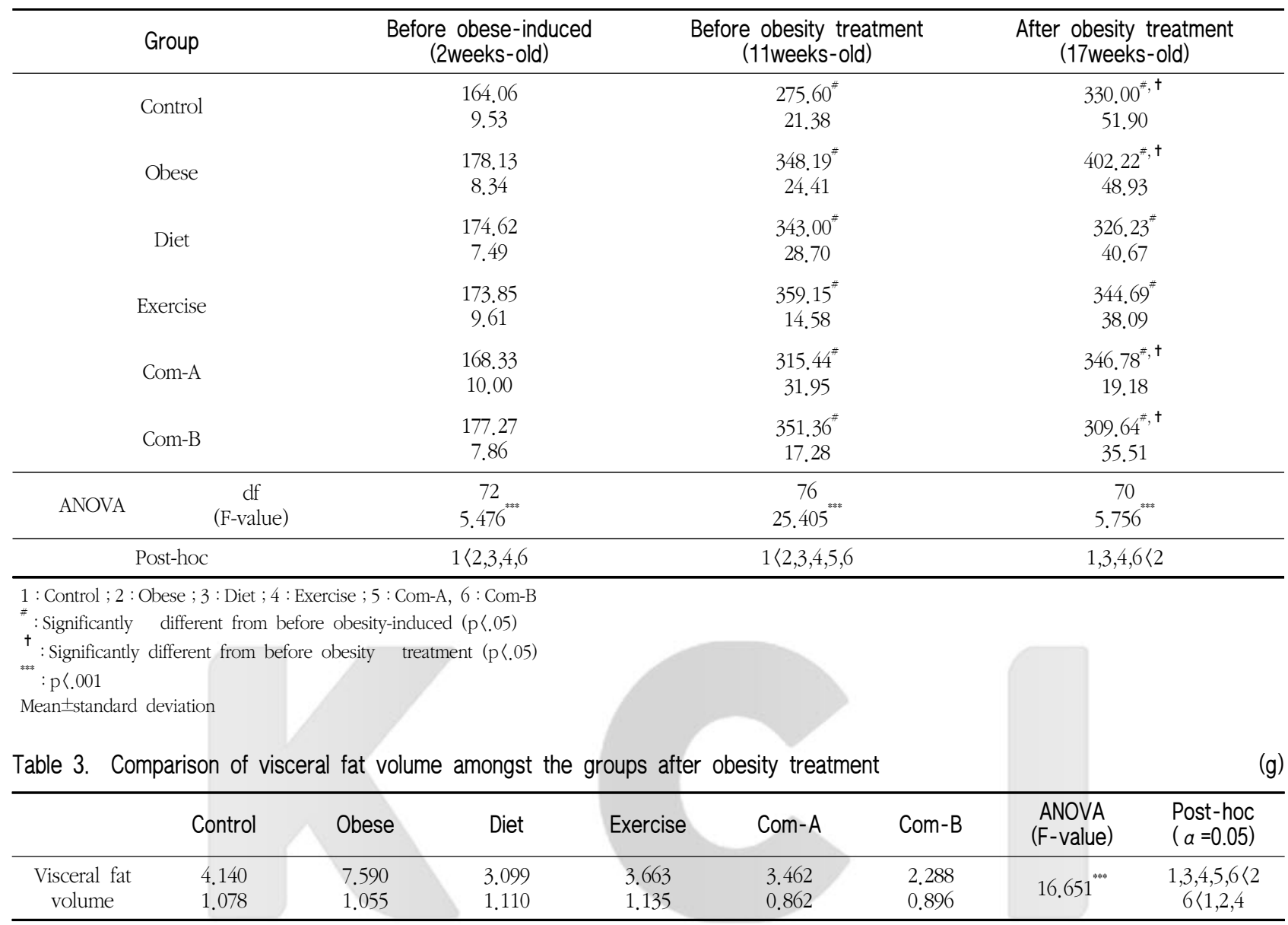

$1:$ Control ; $2:$ Obese ; $3:$ Diet ; 4 : Exercise ; $5:$ Com-A, $6:$ Com-B

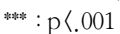

Mean \pm standard deviation

post-obesity treatment, each group showed a significant difference $(p<.001)$, and there was also a significant difference in each group after obesity treatment $(p<.001)$. Before obesity-induced, obese, diet, and combined(B) groups represented a significantly higher level $(p<.05)$ than control group in the result of post-hoc test of each group. However, after obesity-induced and before obesity treatment, control group showed lower body weight $(p<.05)$ than obese, diet, combined(A), and combined(B) groups. After obesity treatment, a significant increase in weight $(p<.05)$ was observed in obese group than all other groups except for the combined (A) group. All groups showed an increase in weight before obesity treatment $(p<.05)$ when compared to before obesity-induced treatment. After six-weeks of obesity treatment, control, obese, and combined(A) group demonstrated significant increase in weight $(p<.05)$. Though diet and exercise group showed no significance, there was a slight decrease in weight. The combined(B) group showed a significantly decrease in weight.

\section{Changes in visceral fat volume}

The results of measurement of visceral fat volume around the testicles are shown in $\langle$ Table 3$\rangle$ and $\langle$ fig. 1$\rangle$. The visceral fat volume displayed similar trend of increase in weight. In the one-way ANOVA the difference in visceral fat volume among groups showed statistical significance $(p<.001)$. In the post-hoc test among groups, diet and combined(B) group showed statistical significance $(p<.05)$ with lower volume of visceral fat. As shown in 〈fig. 1〉, obese group showed significantly higher volume of visceral fat $(p<.05)$ as compared to all the other groups, however, there was no statistical significance among control, diet, exercise, and combined(A) group. 


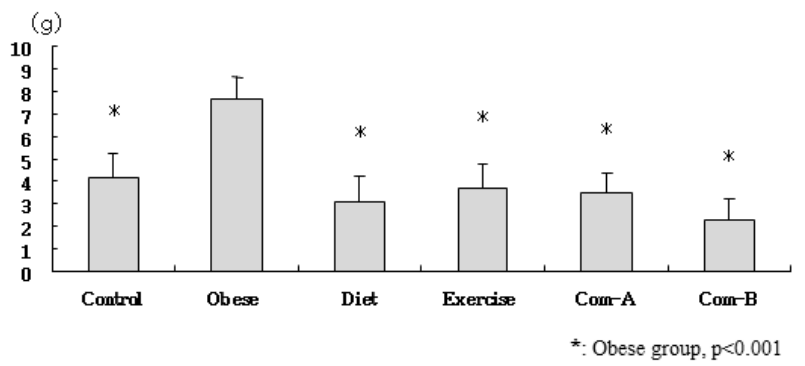

Fig. 1. Comparison of visceral fat volume by group after obesity treatment

\section{VEGF protein expression within skeletal muscle}

1) VEGF protein expression in red muscle of gastrocnemius

The results of measurement of VEGF protein expression in red muscle of the gastrocnemius of each group are shown in 〈fig. 2〉. Based on one-way ANOVA, statistically significant differences $(p<.05)$ were observed in each group. In the post hoc test, diet and combined(B) groups represented significantly $(p<.05)$ higher VEGF protein expression than the control group. Though high VEGF protein expression was observed in other groups, no statistically significant differences were noted.

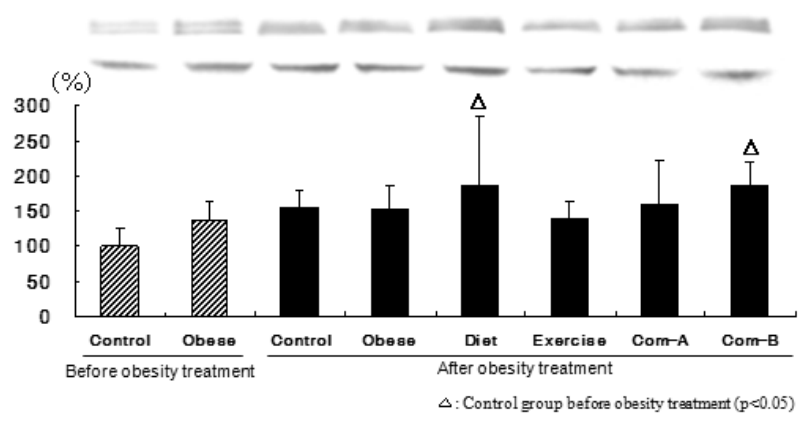

Fig. 2. Comparison of VEGF protein expression in red muscle of gastrocnemius by group

2) VEGF protein expression in white muscle of gastrocnemius

The results of measurement of VEGF protein expression in white muscle of the gastrocnemius of each group are demonstrated in 〈fig. 3〉. Based on one-way ANOVA, statistically significant $(p<.001)$ differences were observed among different groups. In the post hoc test, exercise, diet and combined(B) groups showed significantly ( $p<.05)$ higher amount of VEGF protein expression than obese group before obesity treatment. However, none of the groups showed significant differences after obesity treatment in comparison to the control group before obesity treatment.

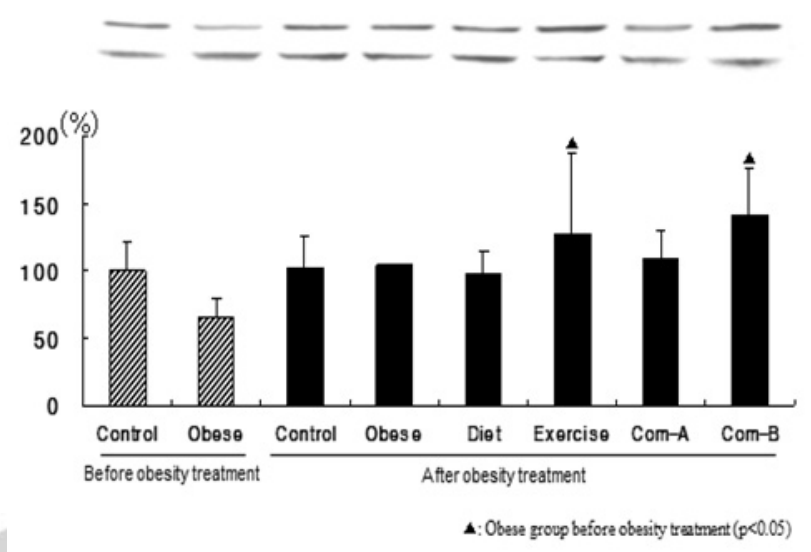

Fig. 3. Comparison of VEGF protein expression in white muscle of gastrocnemius by group

3) VEGF protein expression in soleus

To compare differences in VEGF protein expression in the soleus amongst the groups, one way ANOVA was implemented. The results showed statistical significance $(p<.01)$ among the different groups. In the post hoc test, the exercise group represented a significantly $(p<.05)$ higher VEGF protein expression level as compared to the control group. After obesity treatment, diet and exercise groups showed significantly $(p<.05)$ higher VEGF protein expression than the control group. However, combined(A) and (B) groups did not show any

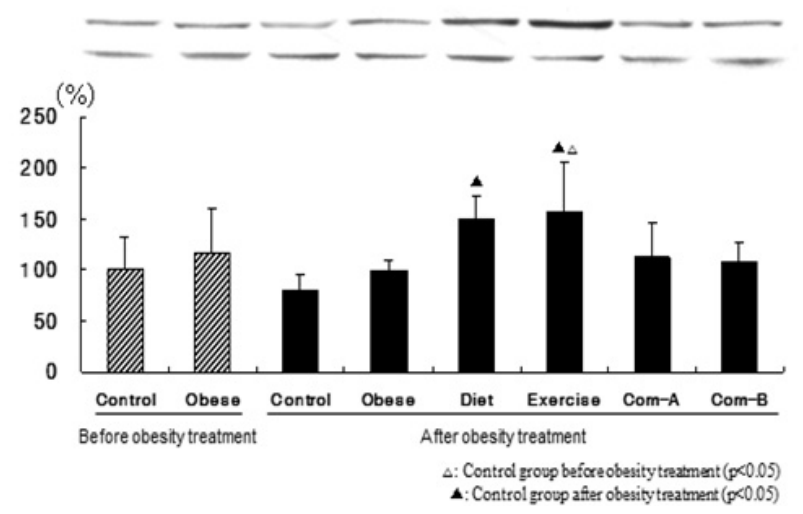

Fig. 4. Comparison of VEGF protein expression in soleus by group 
significant change. To verify the differences among groups and times after obesity treatment, repeated two way ANOVA was implemented. The results showed that groups had significant ( $p<.001)$ differences but there was no significant difference in times. In addition, no interaction between group and times was observed.

\section{Discussion}

\section{The changes in body weight and visceral fat volume}

After six-weeks of treatment, control and combined(A) groups showed a significant increase in $(p<.05)$ body weight. However, diet and combined(B) groups showed a significant $(p<.05)$ decrease in body weight. All the groups except for the diet and combined(B) group failed to achieve a significant weight decrease in spite of 6 -week treatments ; however, the changes in visceral fat volume represented more results that are detailed. The obese group contained the highest visceral fat volume with $7.59 \pm 1.06 \mathrm{~kg}$, whereas the control group had $4.14 \pm 1.08 \mathrm{~kg}$. Diet, exercise, combined(A), and combined(B) groups, which received no obesity treatment showed significantly lower visceral fat volume than the obese group. Moreover, diet and combined(B) groups represented significantly lower visceral fat volume than control and exercise groups. It is reported that aerobatic training obtains most of the necessary energy from fat, and increases the density of capillary vessels in muscle, and stimulates the activation of an enzyme, which controls lipoprotein lipase(LPL) and $\beta$-oxidation (Lacour, 2001). In addition, study results regarding the relation between exercise and lipid metabolism have been widely reported. According to the study on high fat diet or endurance exercise implemented on rats, the trained group showed a significantly lower concentration of blood plasma TG and high density lipoprotein-cholesterol(HDL-C) (Cha et al., 1999). A number of researches have been carried out on exercise and activation of fat metabolism.

Based on the loss of visceral fat volume, it was observed that the treatment carried out in this study had an effect on reducing body fat of rats. Moreover, the treatment program was in correspondence with the purpose of this study, which aimed at investigating the effects of exercise and diet on angiogenesis according to body composition, along with loss of body fat.

\section{VEGF protein expression according to the features of skeletal muscle of obese and normal rats.}

The two groups that did not have any special treatment showed no significant changes in VEGF protein expression from pre-to post-treatment. In addition, there was no significant difference between the control group and obese group. This observation coincides with the study of Galvin et al.(2005) reporting that there was no significant difference in VEGF mRNA and VEGF receptor analyzed between obese and normal people.

After obesity was induced, diet, exercise, diet and exercised combined treatment programs were implemented in each group. The results of groups with treatment showed increased trends of VEGF protein expression when compared to control group, although little difference was observed according to the features of skeletal muscle among treatments. Especially in the white muscle of gastrocnemius featuring typellb fiber, the effects of exercise was distinctive, and it seemed to be influenced by the total amount of exercise. Exercise group, and diet and exercised combined(B) group, which had the same amount of exercise, showed a similar increase in the level of VEGF protein expression post-obesity treatment $(p<.05)$. Additionally, the exercise group showed a significant ( $p<.05)$ increase in soleus when compared to control and obese groups before obesity treatment. Diet group represented a significant increase in VEGF protein expression in red muscle of gastrocnemius and soleus. These results signify that the amount of exercise based on diet and duration of exercise plays an important role in VEGF protein expression.

Based on the results of analysis on optimum strength of exercise for VEGF protein expression conducted by many researchers, an increase in VEGF protein expression in skeletal muscle was found to be in coincidence with decrease in $\mathrm{PO}_{2}$ 
inside cells during the exercise strength of $55 \%$ of Maximal oxygen intake( $\left.\mathrm{VO}_{2} \max \right)$ (Gavin \& Wagner, 2001 ; Breen et al., 1996 ; ,Gustafsson et al., 1999). Breen et al. (1996) exercised rats on the treadmill for an hour, and then analyzed mRNA of VEGF, bFGF and transforming growth factor $\beta 1$ (TGF- $\beta 1$ ). Exercise at $20 \mathrm{~m} / \mathrm{min}$ resulted in a higher mRNA expression of angiogenesis factors when compared to exercise at $15 \mathrm{~m} / \mathrm{min}$. Hashimoto et al.(1994) reported that VEGF mRNA in hypoxia induced cardiac muscles, started to increase within 30 minutes, and reached the maximum in one or two hours, and then recovered to normal level three hours later. Moreover, in the study of VEGF protein of skeletal muscles exposed to hypoxia condition in rats, the result of analysis reported significantly high VEGF protein expression in gastrocnemius and soleus an hour later after induction of exercise (Kim et al., 2005).

In a study on training of high-living low program for 6-weeks in the condition of hypoxia 3850 meters above the sea level with trained athletes, the group with higher intensity of exercise showed higher VEGF mRNA level (Hoppeler \& Vogt, 2001). Therefore, it can be considered that exercise amount and intensity have possible high effects on level of VEGF protein expression. The intensity difference of exercise was not applied to exercise treatment in this study, so further studies with respect to exercise intensity are required. From the present results, it is apparent that exercise, and diet and exercise combined(B) groups, which relatively had more amount of exercise than diet, and diet and exercise combined(A), showed a increased VEGF protein expression. It is also considered that sufficient exercise duration can effectively provide sufficient stimulation for angiogenesis.

The diet group in this study showed a significant $(p<.05)$ increase in red muscle of gastrocnemius and soleus. On the contrary, studies on diet or fasting resulted in decreased VEGF concentration in the blood (Wang et al., 2003). In the study of correlation between visceral fat volume and serum VEGF concentration, visceral fat area of obese people was found to be in close relation to serum VEGF concentration (Miyazawa -Hoshimoto et al., 2003). In addition, it has been reported that people with problems in coronary arteries are related to high serum VEGF levels(Blann et al., 2002). As obese people with increased fat volume experience a decrease in body fat or visceral fat volume through obesity treatment, a decrease in VEGF level can be induced in such cases; however, it is contrary to the results of this study. The other study on investigating relation between VEGF and glucose concentration reported that partial hypoglycemia induces VEGF mRNA expression. The study represented that ATP decrease inside cell due to the shortage of glucose considered, as a necessary factor to induce angiogenesis is one of the main causes of an increase in VEGF mRNA expression (Satake et al., 1998). However, Williams and others (Williams et al., 1997) reported contrary results stating that decreased glucose concentration could not increase VEGF mRNA expression and protein production of vascular smooth muscle cells, and hypoglycemia had no direct influence on the VEGF level. As above, it is difficult to clarify the trends of VEGF protein of skeletal muscle according to diet. To represent descriptive and convincible results, a more detailed method in comparison to diet has to be carried out by specifying limited calories of divided steps, breaking down nutrient intake rate, and implementing continuous analysis on variables related to blood factor, mRNA, and protein levels.

In the beginning of the study, same number of rats was divided into each treatment group, but the sample size was unbalanced due to some of rats died during the period of exercise treatment. However, there was no problem to confirm the changing tendency of variables.

In conclusion, VEGF protein expression in skeletal muscle represented a significant increase in white muscle of gastrocnemius featuring typeIIb fiber through exercise training, and this increase had a high possibility to be influenced by differences in exercise duration. Therefore, continuous exercise is considered as an effective way to provide sufficient stimulation for angiogenesis. However, the results from the present study are insufficient to explain clearly the increase in VEGF protein expression based on diet.

\section{Reference}

Annex, B. H., Torgan, C. E., Lin, P., Taylor, D. A., Thompson, M. V., \& Peters, K. G., et al. (1998). Induction and maintenance of increased VEGF protein by chronic 
motor nerve stimulation in skeletal muscle. The American Journal of Physiology, 274 : H860-H867.

Birot, O. J., Koulmann, N., Peinnequin, A., \& Bigard, X. A.

(2003). Exercise-induced expression of vascular endothelial growth factor mRNA in rat skeletal muscle is dependent on fibre type. The Journal of Physiology, $552: 213-221$.

Blann, A. D., Belgore, F. M., McCollum, C. N., Silverman, S., Lip, P. L., \& Lip, G. Y. (2002). Vascular endothelial growth factor and its receptor, Flt-1, in the plasma of patients with coronary or peripheral atherosclerosis, or type II diabetes. Clinical Science, $102: 187-194$.

Breen, E. C., Johnson, E. C., Wagner, H., Tseng, H. M., Sung, L. A., \& Wagner, P. D. (1996). Angiogenic growth factor mRNA responses in muscle to a single bout of exercise. Journal of Applied Physiology, $81: 355-361$.

Brutsaert, T. D., Gavin, T. P., Fu, Z., Breen, E. C., Tang, K., \& Mathieu-Costello, O., et al. (2002). Regional differences in expression of VEGF mRNA in rat gastrocnemius following $1 \mathrm{hr}$ or electrical stimulation. BMC Physiology, $2: 8-17$.

Cha, Y. S., Sohn, H. S., DailyII' ${ }^{3}$ J. W., \& Oh, S. H. (1999). Effects of exercise training and/or high fat diet on lipid metabolism and carnitine concentrations in rat. Nutrition Research, $19:$ 934-945.

Gavin, T. P., Stallings, H. W., Zwetsloot, K. A., Westerkamp, L. M., Ryan, N. A., \& Moore, R. A., et al. (2005). Lower capillary density but no difference in VEGF expression in obese vs. lean young skeletal muscle in humans. Journal of Applied Physiology, $98: 315-321$.

Gavin, T. P., \& Wagner, P. D. (2001). Effect of short-term exercise training on angiogenic-growth factor gene responses in rats. Journal of Applied Physiology, 90 : 1219-1226.

Gu, J. W., Shparago, M., Tan, W., \& Bailey, A. P. (2006). Tissue endostatin correlates inversely with capillary network in rat heart and skeletal muscles. Angiogenesis, 9: 93-99.

Gustafsson, T., Adrian, P., Lennart, K., Eva, J., \& Carl, J. S. (1999). Exercise-induced expression of angiogenesis

Tang, K., Breen, E. C., Wagner, H., Brutsaert, T. D., -related transcription and growth factors in human skeletal muscle. The American Journal of Physiology, 276 : H679-685.

Gustafsson, T., Bodin, K., Sylven, C., Gordon, A., Tyni-Lenne, R., \& Jansson, E. (2001). Increased expression of VEGF following exercise training in patients with heart failure. European Journal of Clinical Investigation, 31 : 362-366.

Hashimoto, E., Ogita, T., Nakaoka, T., Matsuoka, R., Tseng, A., \& Kira, Y. (1994). Rapid induction of vascular endothelial growth factor expression by transient ischemia in rat heart. The American Journal of Physiology, 267 : H1948-H1954.

Hoppeler, H., \& Vogt, M. (2001). Hypoxia training for sea-level performance. Training high-living low. Advances in Experimental Medicine and Biology, 502 : 61-73.

Jensen, L., Bangsbo, J., \& Hellsten, Y. (2004). Effect of high intensity training on capillarisation and presence of angiogenic factors in human skeletal muscle. The Journal of Physiology, $557: 571-582$.

Kim, J. C., Ha, K. S., Yoon, J. S., Kang, H. S., \& Kim, C. K. (2005). Effects of hypoxia on expression of VEGF mRNA and protein in skeletal muscle. The Journal of Korean Alliance for Health, Physical Education, Recreation, and Dance, 44 : 207-214.

Lacour, J. R. (2001). Lipid metabolism and exercise. La Revue du Praticien, $51:$ S36-41.

Miyazawa-Hoshimoto, S., Takahashi, K., Bujo, H., Hashimoto, N., \& Saito, Y. (2003). Elevated serum vascular endothelial growth factor is associated with visceral fat accumulation in human obese subjects. Diabetologia, 4 $6: 1483-1488$.

Olfer, I. M., Breen, E. C., Costello, O. M., \& Wagner, P. D. (2001). Chronic hypoxia attenuates resting and exercise-induced VEGF, flt-1, and flk-1 mRNA levels in skeletal muscle. Journal of Applied Physiology, 90 : $1532-1538$

Satake, S., Kuzuya, M., Miura, H., Asai, T., Ramos, M. A., \& Muraguchi, M., et al. (1998). Up-regulation of vascular endothelial growth factor in response to glucose deprivation. Biologie Cellulaire, $90: 161-168$.

Gassmann, M., \& Wagner, P. D. (2004). HIF and VEGF 
relationships in response to hypoxia and sciatic nerve stimulation in rat gastrocnemius. Respiratory physiology \& neurobiology, $144: 71-80$.

Wang, X., McCormick, K., \& Mick, G. (2003). Nutritional regulation of white adipocyte vascular endothelial growth factor. Hormone and Metabolic Research, 35 :
211-216.

Williams, B., Gallacher, B., Patel, H., \& Orme, C. (1997). Glucose-induced protein kinase $\mathrm{C}$ activation regulates vascular permeability factor mRNA expression and peptide production by human vascular smooth muscle cells in vitro. Diabetes, $46: 1497-1503$.
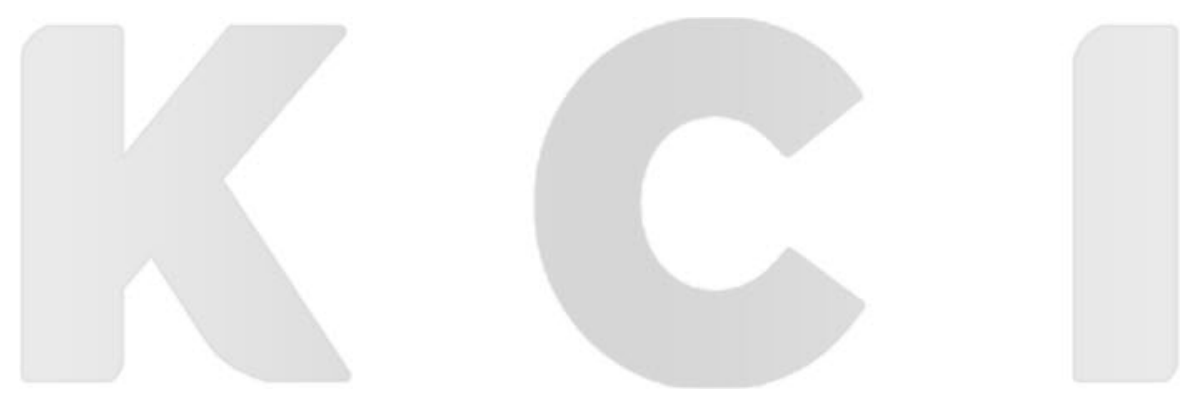

논문투고일 : 2012. 05. 31 